\title{
Otizm Spektrum Bozukluğuna Sahip Kardeşi Olan Ergenlerin Yılmazlık Kaynakları İle Kardeşlerine Yönelik Tutumlarının İncelenmesi
}

\author{
Examining Resilience Sources of Adolescents Who Have Siblings with Autism Spectrum \\ Disorders and Attitudes towards Their Siblings
}

\section{Eylem YOKUŞ YILMAZ[1] Sakine Gülfem ÇAKIR ÇELEBİ[2]}

Araştırmanın amacı, Otizm Spektrum Bozukluğuna (OSB) sahip kardeşi olan ergenlerin yılmazlık kaynakları ve kardeşe yönelik tutumlarında çeşitli demografik değişkenlere göre anlamlı bir farklılık olup olmadığını incelemektir. Araştırmanın bir diğer amacı ise OSB'ye sahip kardeşi olan ergenlerin yılmazlık kaynaklarının engelli kardeşlerine yönelik tutumlarını anlamlı bir şekilde yordayıp yordamadığını incelemektir. Çalışma grubunu Denizli ve İzmir ilinde yaşayan ve OSB'ye sahip kardeşi olan 254 ergen olușturmaktadır. Katılımcıların yaș aralığı 11 ile 18 arasında değișmekte olup katılımcıların 123'ü kız, 131'i erkektir. Araștırmanın verileri 2016-2018 yılları arasında toplanmıştır. Bu çalışmada veri toplama aracı olarak Engelli Kardeşe Yönelik Tutum Ölçeği, Çocuklar İçin Yılmazlık Ölçeği ve Kişisel Bilgi Formu kullanılmıştır. Araştırmada Mann Whitney-U analizinin sonuçlarında cinsiyet değişkenine göre yılmazlık kaynaklarının arkadaş alt boyutunda, bakıma yardımcı birinin varlığı değişkenine göre yılmazlık kaynaklarının okul-öğretmen alt boyutunda ve kardeșe yönelik tutumun kardeșin özelliklerine ilişkin düşünce alt boyutunda anlamlı bir farklılık olduğu bulunmuştur. Araştırmada Kruskal Wallis analizinin sonuçlarında, ailenin içinde yer aldığ gelir grubu değişkenine göre yılmazlık kaynaklarının ve kardeşe yönelik tutumun tüm alt boyutlarında anlamlı bir farklılık olduğu bulgulanmıştır. Çoklu regresyon analizi sonucunda yılmazlık kaynaklarından kendisi ve arkadaş alt boyutlarının kardeşi ile yaşamaya ilişkin duygu ve düşünce puanlarını, yılmazlık kaynaklarından arkadaş ve okul-öğretmen alt boyutlarının kardeşin özelliklerine ilişkin düşünce puanlarını ve yılmazlık kaynaklarından aile, kendisi ve arkadaş alt boyutlarının kardeşin durumuna ilişkin üzüntü, endişe puanlarını anlamlı bir șekilde yordadığı bulunmuştur.

Anahtar Kelimeler: yılmazlık, engelli kardeșe yönelik tutum, otizm spektrum bozukluğu, ergenlik

Received Date:03 February 2021

Accepted Date:25 May 2021

The aim of this study is to examine whether there are significant differences in resilience sources and the attitudes of individuals who have siblings with ASD in terms of some demographic variables. The other aim of the study was to investigate whether resilience sources of individuals with siblings with ASD predict their attitudes towards disabled siblings. The research group is composed 254 adolescents who have siblings with ASD, living in Denizli and İzmir. The age range of participants ranged from 11 to 18, 123 are girls and 131 are boys. The data is collected during 2016-2018 years. In this study, data collection instruments were Attitude Scale for Disabled Sibling, Resilience Scale for Children and Personal Information Form. According to the results of Mann Whitney-U analysis, there was a significant difference in the sub-dimension of resilience sources according to gender variable. It was found that there was a significant difference in school-teacher sub-dimension and thought about the sibling's characteristics subdimension of attitude towards the sibling according to presence of helper for the caring of the child. According to the results of the Kruskal Wallis analysis, there was a significant difference in all sub-dimensions of resilience sources and attitude towards siblings according to family's income group variable. As a result of multiple regression analysis, it was found that the resilience sources significantly predicted the emotion and thoughts about living with the sibling. Among the resilience sources, it was found that the sub-dimensions of friends and school-teachers significantly predicted the thought about the sibling's characteristics. Among the resilience sources, it was found that the sub-dimensions of family, oneself and friends significantly predicted sadness and anxiety scores about the sibling's status.

Keywords: resilience, attitude towards disabled sibling, autism spectrum disorder, adolescence ile kardeşlerine yönelik tutumlarının incelenmesi. Humanistic Perspective, 3 (2), 477-495. https://doi.org/10.47793/hp.849880

[1] Uzman Psikolojik Danışman | Milli Eğitim Bakanlığı | İzmir | Türkiye | ORCID: 0000-0001-7139-114X | eylemyks@gmail.com [2] Doç. Dr. | Akdeniz Üniversitesi| Eğitim Fakültesi | Antalya | Türkiye | ORCID: 0000-0003-0625-3802 


\section{GíRis}

A ileye katılan yeni bir kardeș, aile üyelerinin her biri için ayrı bir anlam ifade etmektedir. Yeni gelen kardeşin özel gereksinimli olması yine her üye için farklı bir anlam taşıyabilmektedir (Aykara, 2015). Kardeş ilişkisinin temeli erken çocukluk dönemine dayanmaktadır. Kardeşler bu dönemde birbirleri için sürekli bir arkadaşlık kaynağıdırlar. Bu dönemdeki sıcaklık ve sevgi ileriki dönemlerdeki yakınlık ve korumanın temelini oluşturur. Büyük kardeş ve küçük kardeșin rolleri de yaş artışına bağlı olarak değişir ve yeniden düzenlenir (Onat Zoylan, 2005).

Engelli kardeşe sahip olan bireyler için bu süreç biraz daha farklı seyredebilmekte ve bu sürecin niteliği değiş̧ebilmektedir (Şenel, 1995). Engelli bir kardeşe sahip olma, çocukların sosyal duygusal süreçlerini olumsuz etkileyip duygusal tepkilerinde; kızgınlık, düşmanlık, kıskançlık, suçluluk, üzüntü, endişe, korku, utanma ve sıkıntı, reddetme gibi olumsuz duyguları yaşamalarına neden olabilir (İçöz, 2001). Bu durum engelli kardeşe yönelik tutumlar açısından da ele alınabilmektedir. Engelli kardeşe yönelik tutum, normal gelişim gösteren çocuğun, özel gereksinimli kardeşine ilişkin üzüntüsü, endişesi ve duygularına karşı aldığı durum, tutulan yol ve davranış eğilimlerini içermektedir (Dolanay, 2016). Her ne kadar bu süreç engelli kardeşi olan çocuklar için belli zorlukları taşıyor olsa da, kardeş ilişkilerini olumlu ya da olumsuz etkileyebilen bazı demografik ya da aile ile ilgili değişkenlerden söz etmek mümkündür. $\mathrm{Bu}$ faktörlere ilişkin olarak ortaya çıkan farklılıkların kaynağının belirlenmesi, kardeș ilişkilerini yorumlamada aile ve kardeşler için çözüm yollarını belirlemede yol gösterici olabilmektedir (Korkmaz, 2008). Bu nedenle, bu araştırmanın amaçlarından biri, Otizm Spektrum Bozukluğuna (OSB) sahip kardeşi olan bireylerin kardeşlerine yönelik tutumları ve yılmazlık kaynaklarının çeşitli demografik değişkenler (kendi cinsiyeti, kardeşinin cinsiyeti, engel türü, engel derecesi, ailenin gelir düzeyi ve bakıma yardımcı kişinin var olup olmadı̆̆ı) açısından incelenmesidir.

Engelli kardeşe sahip bireylerin baş etme mekanizmaları geliştirmelerinde önemli bir diğer faktör de sosyal destek sistemidir (Aykara, 2015). Yılmazlık kaynakları bu destek mekanizmalarından biridir. Yılmazlık, potansiyel olarak yaşamı değiştiren deneyimlere maruz kalma sırasında veya sonrasında başarılı bir yaşam boyu gelişim sürecinin kapasitesini, süreçlerini ve sonuçlarını içeren, önemli zorluklar karşısında olumlu uyum gösterme becerisi olarak tanımlanmaktadır (Masten ve Reed, 2002). Yani yılmazlık kavramı sadece olumsuz yaşantılar karşısında zarar görmemek anlamına gelmemektedir. Yılmazlık kavramının en temel unsuru olumsuz yaşantılar sonrasında psikolojik olarak yeniden ve daha güçlü hale gelmektir (Olsson, Bond, Burns, Vella-Brodrick ve Sawyer, 2003).

Bireylerin kişilik özellikleri ve yașam becerileri, ailede, toplumda ve öğrencilik yıllarında okul ortamında geliştirilebildiği gibi bireyin yılmazlık kaynakları da güçlendirilerek yılmazlık 
düzeyi geliştirilebilir (Çelik, 2013). Yılmazlık bireylerin benzer durumlar karşısında farklı tepkiler vermelerinin nedenini de açılamaya yardımcı olmaktadır. Bireyin koruyucu faktörlerinin geliştirilmesiyle birlikte kişinin yılmazlık kaynakları oluşturulacak ve bu sayede de bireyin davranışları anlamlandırılabilecektir. Özellikle ergenlik dönemindeki bireyin davranışlarının anlamlandırılmasında ve uyum becerisinin gelişmesinde yılmazlık kaynakları rehberlik edecektir (Burke, 2004).

Newman (2004) ergenlik döneminde çocukların sahip olması gereken yılmazlık kaynaklarını, sorunlar karşısındaki baş etme becerisine sahip olmak, özgüven sahibi olmak, bağımsız hareket edebilme becerisine sahip olmak, koşulsuz destekleyici bir ebeveyne sahip olmak, olumlu okul yaşantısı, arkadaşlardan oluşan güçlü sosyal destek ağına sahip olmak, duygularını ve düşüncelerini ifade edebilme becerisine sahip olmak olarak sınıflandırmıștır.

Özellikle engelli kardeşe sahip, ergenlik dönemindeki çocuklarda yetkinlik ve yılmazlığın gelişimi olumlu duygular ile ilişkilidir (Clonan ve arkadaşları, 2004). Sosyal ve duygusal kaynaklarının güçlendirilmesiyle birlikte çocuğun kendine ve engelli kardeşine yönelik olumlu duyguları artacaktır. Olumlu duygu gelişimin ardından olumlu davranış gelişimi yaşanacak ve çocuğun uyum becerileri artacaktır (Bear, Manning ve Izard, 2003).

$\mathrm{Bu}$ nedenle, araştırmanın ikinci amacı, OSB'ye sahip kardeşi olan bireylerin yılmazlık kaynaklarının (kendisi, aile, arkadaş ve okul-öğretmen) kardeşlerine yönelik tutumlarını yordayıcılı̆̆ının incelenmesidir. Bu amaçlar doğrultusunda aşağıdaki alt problemlere yanıt aranacaktır:

OSB'ye sahip kardeşi olan yılmazlık düzeylerinde cinsiyete, engel türüne, kardeșin engel derecesine göre, kardeşin bakımına yardımıının varlığına, kardeşin cinsiyetine, ailenin içinde yer aldı̆̆ı gelir grubuna göre anlamlı bir fark var mıdır?

OSB'ye sahip kardeşi olan bireylerin kardeșe yönelik tutumlarında cinsiyete, engel türüne, kardeşin engel derecesine göre, kardeșin bakımına yardımcının varlığına, kardeșin cinsiyetine, ailenin içinde yer aldığı gelir grubuna göre anlamlı bir fark var mıdır?

OSB’ye sahip kardeşi olan bireylerin yılmazlık kaynakları engelli kardeşlerine yönelik tutumlarını anlamlı bir şekilde yordamakta mıdır?

Ülkemizde özel gereksinimli çocuk sayısı oldukça fazla olmasına rağmen onların yaşam standartları, aile dinamikleri ve kardeş ilişkilerine yönelik sınırlı sayıda araştırma bulunmaktadır. Bu çalışmada Otizm Spektrum Bozukluğu'na (OSB) sahip kardeşi olan ergenlik dönemindeki bireylerle çalışılmıştır. Ergenlik dönemi çocukların kimlik arayışına girdikleri, fiziksel, zihinsel ve duygusal açıdan gelişim ve değişimi oldukça hızlı ve derinden yaşadıkları bir dönemdir. Geçmiş yıllarda sayıca az da olsa yapılan çalıșmalarda engelli bireylerin eğitiminde 
sağlıklı olan kardeşi de sürece dahil etmenin önemi saptanmıştır. Sağlıklı kardeşlerin yaşamış oldukları sorunlarla baş etme becerilerinin gelişmesi için, uygulanabilir psikoeğitim programları, psikolojik destek çalışmaları ve aileye yönelik kardeşi de merkeze alan sosyal yardım hizmetleri çalışmalarının yaygınlaştırılması engelli kardeşe sahip bireylerin sağlıklı gelişimini desteklemek adına oldukça önem taşımaktadır (Aykara, 2015). Engelli bir çocuğa sahip anne babalar üzerine yapılan çalışmaların sayısı artmakla birlikte sağlıklı kardeş üzerine yapılan çalışmaların hem sayısı hem de etkililiği son derece azdır. (Aykara, 2015). Bu nedenle, bu araştırmanın bulgularının OSB'ye sahip kardeşi olan ergenlerin kardeşlerine yönelik olumlu tutum geliştirmeleri için gerekli becerileri kazandırmaya yönelik oluşturulacak olan psikoeğitim, destek ve psikolojik danışma grupları için önemli bilgiler sağlayacağı düșünülmektedir.

\section{YÖNTEM}

\section{Araştırma Modeli}

$\mathrm{Bu}$ araştırmada nicel araştırma yöntemleri arasında bulunan ilişkisel araştırma modeli kullanılmıştır. İlişkisel araştırma modeli, iki veya daha fazla değişken arasındaki ilişkinin bu değişkenlere müdahale edilmeksizin incelendiği araștırma türü olarak açıklanmaktadır (Büyüköztürk, Çakmak, Akgün, Karadeniz ve Demirel, 2018).

\section{Calışma Grubu}

Araştırmanın çalışma grubunu Denizli ve İzmir ilinde yaşayan ve Otizm Spektrum Bozukluğuna sahip kardeşi olan 254 ergen oluşturmaktadır. Araştırmanın verileri 2016-2018 yılları arasında ortaokul ve lise öğrencilerinden toplanmıștır. Katılımcıların ulaşılabilirliğinin zor olması nedeniyle çalışma grubu, Denizli ve İzmir illerinde yer alan çeşitli ortaokul ve liseler ile özel eğitim merkezlerine devam eden öğrencilerin kardeşlerinden seçilmiştir. Araştırmanın çalışma grubunu \%51.2 kız, \%48.8 erkek öğrenci oluşturmaktadır. Araştırmaya katılan öğrencilerin yaşları 11-18 (ortalama- 14.5) yaş arasında değişmektedir. Araştırmaya katılan öğrencilerin kardeşlerinin cinsiyete göre dağılımları \%48.4kız, \%51.6 erkektir. Katılımcıların kardeşlerinin engel derecesine göre dağllımları, \%25.6 hafif düzeyde, \%59.4 orta düzeyde ve \%15 ağır düzeydedir. Katılımcıların kardeşlerinin engel türleri açısından incelendiğinde Otizm Spektrum Bozukluğu (OSB) içerisinde kardeşlerin \%24.8'i Otizm ve \%75.2'i Çocukluk Dezintegratif Bozukluğuna sahiptir. Engelli kardeşin bakımına yardımcı bir kişi \%25.6 katılımcının evinde vardır, \%74.4 katılımcının evinde yoktur. Katılımcıların içinde yer aldıkları ailelerin 71 (\%27.9) tanesinin aylık geliri 1600 TL'ye kadardır. Yüz on dokuz (\%46.9) tanesinin aylık geliri 1601 TL- 4000 TL arasındadır. Altmıș dört (\% 25.2) tanesinin aylık geliri 4001 TL8000 TL arasındadır. 


\section{Verilerin Toplanması}

Araştırmanın verileri 2016-2018 yılları arasında Denizli ve İzmir illerinde yaşayan OSB'ye sahip kardeşi olan ortaokul ve lise düzeyindeki ergenlerden toplanmıştır. Araştırmada veri toplama aracı olarak Engelli Kardeșe Yönelik Tutum Ölçeği, Çocuklar için Yılmazlık Ölçeği ve kişisel bilgi formu kullanılmıştır. Veri toplama araçları birinci yazar tarafından gönüllü olan ergenlere uygulanmıştır. Ölçeklerin uygulama süresi yaklaşık olarak 20-30 dakika sürmüştür. Uygulama öncesinde araştırmanın amacı ve önemi açıklanmış, her iki ölçek için de yönergeler okunmuştur. Ayrıca veri toplama araçlarının içten bir şekilde cevaplandırılmasının araştırmaya büyük katkı sağlayacağı belirtilmiştir.

Engelli Kardeşe Yönelik Tutum Ölçeği. Engelli Kardeşe Yönelik Tutum Ölçeği (EKYTÖ) Küçüker (1997) tarafından sağlıklı çocukların engelli kardeşlerine yönelik tutumlarını belirlemek için geliştirilmiştir. Ölçekte dörtlü Likert (Tamamen Katılıyorum) - (Katılıyorum) (Katılmıyorum) - (Hiç katılmıyorum) dereceleme ölçeği ile değerlendirilen 28 madde yer almaktadır. Ölçekteki maddelerde tutumun biliş, duyuş ve davranış boyutları ele almak için oluşturulmuş olumlu ve olumsuz yargı bildiren cümleler bulunmaktadır. Ölçek 3 alt boyuta sahiptir: kardeşi ile birlikte yaşamaya ilişkin duygu ve düşünce (16 madde), kardeşin özelliklerine ilişkin düşünce (6 madde) ve kardeşin durumuna ilişkin üzüntü ve endișe (6 madde).

Küçüker (1997) tarafından ölçeğin geçerliğini belirlemek için kapsam geçerliği, madde analizi ve yapı geçerliği için de faktör analizi çalışmaları yapılmıştır. Faktör analizi sonucunda belirlenen 3 faktörün birlikte toplam varyansın \%37'sini açıklamaktadır. Ölçeğin güvenirliği ile ilgili kanıt elde etmek için iç tutarlılık katsayıları hesaplanmıştır. Hesaplanan değerler birinci boyut için .83, ikinci boyut için .89 ve üçüncü boyut için .78 olarak bulunmuştur. Analiz sonucunda tüm ölçeğin ve alt boyutlarının kardeșe yönelik tutumu ölçmek için güvenirliğinin kabul edilebilir düzeyde olduğu görülmektedir.

Çocuklar İçin Yılmazlık Ölçeği. Çocuklar için Yılmazlık Ölçeği Baltacı ve Karataş (2013) tarafından ergenlik dönemindeki çocukların algıladıkları yılmazlık düzeylerini ölçmek amacıyla geliştirilmiştir. Ölçeğin geçerliğini ölçmek için deneme formunda tekrarlanan analizler sonucunda toplam varyansın \%48'ini açlklayan, 23 maddeden oluşan bir ölçek geliştirilmiştir. Ölçeğin dört alt boyutu bulunmaktadır. Mevcut araştırmada, Çocuklar İçin Yılmazlık Ölçeğinin analiz sonucunda elde edilen iç tutarlılık katsayıları 'kendi' alt boyutu için .84, aile alt boyutu için .88, arkadaş alt boyutu için .82, okul-öğretmen alt boyutu için .86 olarak bulunmuştur. 
Kişisel Bilgi Formu. Bu form araştırmaya katılan bireylerin cinsiyet, engelli kardeşin cinsiyeti, engel türü, engel derecesi, ailenin gelir düzeyi ve kardeşin bakımına yardımcı birinin varlığı gibi demografik özelliklerini belirlemek amacıyla oluşturulmuştur.

\section{Verilerin Analizi}

Araştırmada katılımcıların yılmazlık kaynakları ve engelli kardeşe yönelik tutumlarında cinsiyete, engel türüne, kardeşin bakımına yardımcının varlık durumuna ve engelli kardeşin cinsiyetine göre anlamlı farklılık olup olmadığını test etmede normallik varsayımı karșllanmadığı için parametrik olmayan analiz yöntemlerinden Mann Whitney-U testi kullanılmıștır. Katılımcıların yılmazlık kaynakları ve engelli kardeșe yönelik tutumlarında ailenin gelir durumuna ve engelli kardeşin engel derecesine göre farklılık olup olmadığını test etmede normallik varsayımı karşılanmadığı için Kruskal Wallis Testi kullanılmıştır. Araştırmada katılımcıların yılmazlık kaynakları alt boyutlarının engelli kardeşlerine yönelik tutumlarını yordayıp yordamadığı regresyon analizi kullanılarak incelenmiştir. Araștırmada anlamlılık düzeyi .05 kabul edilmiştir. Regresyon analizi varsayımları testi içim normallik, çarpıklık, basıklık katsayıları, sabit varyans, çoklu bağıntı katsayıları incelenmiştir. Değişkenlerin dağılımına yönelik normallik katsayılarını göstermek için standardize edilmiş artıkların (rezidüellerin) histogramı ve normal olasılık grafiği kullanılmıştır. Sabit varyansı test etmek için regresyon artıklarının saçıntı grafiği kullanılmıştır. Standardize edilmiş artıkların- histogramı normal bir dağllım göstermektedir. Normal olasılık grafiği 45 derecelik bir çizgiyi göstererek normallik sayıtlılarını karşılamaktadır. Saçıntı grafiğine göre artıklar rastgele ve dengeli bir şekilde dağılarak sabit varyans sayıltısını karşılamaktadır.

\section{BULGULAR VE YORUM}

Bu bölümde araştırmanın bulguları üç ayrı başlık olarak sunulmaktadır.

\section{Katılımcıların Kardeşe Yönelik Tutumlarını Yordayan Demografik Değişkenlere}

\section{İlişkin Bulgular}

OSB'ye sahip kardeşi olan ergenlerin kardeșe yönelik tutumlarının alt ölçek puanlarında kardeşin engel türüne, kardeşin bakımına bir yardımcının varlığına, OSB'ye sahip kardeşin cinsiyetine, ailenin gelir düzeyine ve kardeşin engel derecesine göre farklılık olup olmadığına ilișkin analiz sonuçları Tablo 1'de sunulmaktadır. 
Tablo 1

Değişkenlere Göre Kardeșe Yönelik Tutum Alt Ölçek Puanları

\begin{tabular}{|c|c|c|c|c|c|}
\hline & & $\mathbf{N}$ & Sira Ortalaması & Sira Toplamı & $\bar{Z}$ \\
\hline \multirow{3}{*}{ Özellik Düşünce } & Kardeşin Engel Türü & & & & \multirow{3}{*}{$-4.996^{*}$} \\
\hline & Otizm & 63 & 87.88 & 5536.50 & \\
\hline & ÇDB & 191 & 140.57 & 26848.50 & \\
\hline \multirow{2}{*}{ Üzüntü Endişe } & Otizm & 63 & 145.52 & 9168.00 & \multirow{2}{*}{$-2.264^{*}$} \\
\hline & ÇDB & 191 & 121.55 & 23217.00 & \\
\hline \multirow{3}{*}{ Özellik Düşünce } & Bakıma Yardımcı & & & & \multirow{3}{*}{$-2.577^{*}$} \\
\hline & Evet & 65 & 107.48 & 6986.50 & \\
\hline & Hayır & 189 & 134.38 & 25398.50 & \\
\hline \multirow{3}{*}{ Özellik Düşünce } & Kardeşin Cinsiyeti & & & & \multirow{3}{*}{$-3.022 *$} \\
\hline & $\mathrm{Klz}$ & 123 & 141.70 & 17429.50 & \\
\hline & Erkek & 131 & 114.16 & 14955.50 & \\
\hline \multirow{5}{*}{ Yaşama Duygu Düşünce } & Gelir Grubu & & & & \multirow{4}{*}{$8.190^{*}$} \\
\hline & 1600 'e kadar (A) & 71 & 147.52 & & \\
\hline & $1601-4000(\mathrm{~B})$ & 119 & 123.31 & 2 & \\
\hline & $4001-8000(\mathrm{C})$ & 64 & 113.09 & & \\
\hline & 1600 'e kadar & 71 & 169.42 & & \multirow{3}{*}{$33.669^{*}$} \\
\hline \multirow[t]{2}{*}{ Özellik Düşünce } & $1601-4000$ & 119 & 107.69 & 2 & \\
\hline & $4001-8000$ & 64 & 117.84 & & \\
\hline \multirow{3}{*}{ Üzüntü Endişe } & 1600'e kadar & 71 & 79.96 & & \multirow{3}{*}{$54.628^{*}$} \\
\hline & $1601-4000$ & 119 & 131.86 & 2 & \\
\hline & $4001-8000$ & 64 & 172.13 & & \\
\hline \multirow{4}{*}{ Özellik Düşünce } & Engel Derecesi & & & & \multirow{4}{*}{$64.173^{*}$} \\
\hline & Hafif & 65 & 158.78 & & \\
\hline & Orta & 151 & 135.08 & 2 & \\
\hline & Ağır & 38 & 43.86 & & \\
\hline \multirow{3}{*}{ Üzüntü Endişe } & Hafif & 65 & 99.59 & & \multirow{3}{*}{$32.476^{*}$} \\
\hline & Orta & 151 & 125.30 & 2 & \\
\hline & A ğır & 38 & 183.96 & & \\
\hline
\end{tabular}

Tablo 1'de sunulan analiz sonuçlarına göre Engelli Kardeşe Yönelik Tutum Ölçeği'nin kardeşiyle birlikte yaşamaya ilişkin duygu ve düşünce alt boyutu, kardeşin özelliklerine ilişkin düşünce alt boyutu ve kardeşin durumuna yönelik üzüntü endişe alt boyutu puan sıra ortalamalarında, katılımcıların cinsiyetine göre anlamlı bir farkın olmadığı görülmüștür.

Engelli Kardeşe Yönelik Tutum Ölçeği'nin kardeşin özelliklerine ilişkin düşünce alt boyutu ve kardeşin durumuna yönelik üzüntü endişe alt boyutu puan sıra ortalamalarında, kardeşin engel türüne göre anlamlı bir farkın olduğu görülmüştür. Buna göre, kardeşinin engel türü Çocukluk Dezintegratif Bozukluğu (ÇDB) olan katılımcıların, kardeşin özelliklerine ilişkin düşünce alt boyutu sıra ortalaması kardeşinin engel türü Otizm olan katılımcılardan daha yüksektir. Kardeşinin engel türü Otizm olan katılımcıların kardeşin durumuna yönelik üzüntü ve endişe alt boyutu sıra ortalaması, kardeşinin engel türü ÇDB olan katılımcılardan daha yüksektir.

EKYTÖ’nün alt boyutları arasında sadece kardeşin özelliklerine ilişkin düşünce alt boyutu puan sıra ortalamalarında, kardeşin bakımına yardımcı birinin varlığına göre anlamlı bir farkın olduğu görülmüştür. Buna göre kardeşin bakımına yardımcı biri var olmadığında, kardeşin özelliklerine ilişkin düşünce alt boyutu sıra ortalaması; kardeşin bakımına yardımcı birinin olmasına göre daha yüksektir. 
EKYTÖ'nün alt boyutları arasında sadece kardeşin özelliklerine ilişkin düşünce alt boyutu puan sıra ortalamalarında, kardeşin cinsiyetine göre anlamlı bir fark olduğu görülmektedir. Buna göre kardeşinin cinsiyeti kız olan katılımcıların, kardeşin özelliklerine ilişkin düşünce alt boyutu sıra ortalaması; kardeşinin cinsiyeti erkek olanlara göre daha yüksektir.

EKYTÖ'nün kardeşiyle birlikte yaşamaya ilişkin duygu ve düşünce alt boyutu, kardeşin özelliklerine ilişkin düşünce alt boyutu ve kardeşin durumuna yönelik üzüntü endişe alt boyutu puan sıra ortalamalarında, ailenin içinde yer aldığı gelir grubuna göre anlamlı bir farkın olduğu görülmektedir. Gelir grupları arasındaki anlamlı farkların hangi grup ya da gruplardan kaynaklandığını anlamak için EKYTÖ’nün alt boyutlarına göre Mann Whitney-U testi kullanılarak ikili karşılaştırmalar yapılmıştır. Ailesinin geliri 1600 TL'ye kadar olan gruptaki katılımcıların, kardeşiyle birlikte yaşamaya ilişkin duygu ve düşünce alt boyutu ve kardeşin özelliklerine ilişkin düşünce alt boyutu sıra ortalamaları ailesinin geliri 1601-4000 TL ve 4001-8000 TL arasında olan gruptaki katılımcllardan daha yüksektir. Ailesinin geliri 1601-4000 TL ve 4001-8000 TL arasında olan gruptaki katılımclların, kardeşin durumuna ilişkin üzüntü ve endişe alt boyutu sıra ortalamaları ailesinin geliri 1600 TL'ye kadar olan gruptaki katılımcılardan daha yüksektir. Ayrıca ailesinin geliri 4001-8000 TL arasında olan gruptaki katılımcıların kardeşin durumuna ilişkin üzüntü ve endișe alt boyutu sıra ortalamaları, ailesinin geliri 1601-4000 TL arasında olan gruptaki katılımcılardan daha yüksektir.

EKYTÖ’nün kardeşin özelliklerine ilişkin düşünce alt boyutu ve kardeşin durumuna yönelik üzüntü endişe alt boyutu puan sıra ortalamalarında, kardeşin engel derecesine göre anlamlı bir farkın olduğu görülmektedir. Kardeşin engel dereceleri arasındaki anlamlı farkların hangi grup ya da gruplardan kaynaklandığını anlamak için EKYTÖ’nün alt boyutlarına göre Mann Whitney-U testi kullanılarak ikili karşılaştırmalar yapılmıştır. Kardeşinin engel derecesi orta olan gruptaki katılımcıların, kardeşin durumuna ilişkin üzüntü ve endişe alt boyutu sıra ortalamaları, kardeşinin engel derecesi hafif olan gruptaki katılımcılardan daha yüksektir. Kardeşinin engel derecesi hafif ve orta olan gruptaki katılımcıların kardeşin özelliklerine ilişkin düşünce alt boyutu sıra ortalamaları, kardeşinin engel derecesi ağır olan gruptaki katılımcılardan daha yüksektir. Kardeşinin engel derecesi ağır olan gruptaki katılımcıların kardeşin durumuna ilişkin üzüntü ve endişe alt boyutu sıra ortalamaları, kardeşinin engel derecesi hafif ve orta olan gruptaki katılımcılardan daha yüksektir.

\section{Katılımcıların Yılmazlık Kaynaklarını Yordayan Demografik Değişkenlere İlişkin}

\section{Bulgular}

Otizm Spektrum Bozukluğuna (OSB) sahip kardeşi olan ergenlerin yılmazlık kaynakları alt ölçek puanlarında katılımcıların cinsiyetine, kardeşin engel türüne, kardeşin bakımına bir 
yardımcının varlığına, OSB'ye sahip kardeşin cinsiyetine, ailenin gelir düzeyine ve kardeşin engel derecesine göre farklılık olup olmadığına ilişkin analiz sonuçları Tablo 2'de sunulmaktadır.

Tablo 2

Değişkenlere Göre Çocuklar için Yılmazlık Alt Ölçek Puanları

\begin{tabular}{|c|c|c|c|c|c|}
\hline & & $\mathbf{N}$ & Sıra Ortalaması & Sira Toplamı & $\mathbf{Z}$ \\
\hline & Cinsiyet & & & & \\
\hline \multirow[t]{2}{*}{ Arkadaş } & $\mathrm{K} 1 \mathrm{z}$ & 130 & 136.24 & 17711.50 & $-2.045^{*}$ \\
\hline & Erkek & 124 & 118.33 & 14673.50 & \\
\hline \multirow{3}{*}{ Aile } & Kardeşin Engel Türü & & & & \\
\hline & Otizm & 63 & 146.78 & 9247.00 & $-2.441^{*}$ \\
\hline & ÇDB & 191 & 121.14 & 23138.00 & \\
\hline \multirow{3}{*}{ Okul-Öğretmen } & Bakıma Yardımcı & & & & \\
\hline & Evet & 65 & 111.78 & 7265.50 & $-2.087^{*}$ \\
\hline & Hayır & 189 & 132.91 & 25119.50 & \\
\hline \multirow{3}{*}{ Arkadaş } & Kardeșin Cinsiyeti & & & & \\
\hline & $\mathrm{KlZ}$ & 123 & 138.98 & 17094.00 & $-2.541^{*}$ \\
\hline & Erkek & 131 & 116.73 & 15291.00 & \\
\hline \multirow{4}{*}{ Aile } & Gelir Grubu & & & & \\
\hline & 1600 'e kadar (A) & 71 & 115.63 & & \\
\hline & $1601-4000(B$ & 119 & 122.39 & 2 & $8.801^{*}$ \\
\hline & $4001-8000(\mathrm{C})$ & 64 & 150.16 & & \\
\hline \multirow[t]{3}{*}{ Kendisi } & 1600'e kadar & 71 & 148.87 & & \\
\hline & $1601-4000$ & 119 & 120.80 & 2 & $8.642^{*}$ \\
\hline & $4001-8000$ & 64 & 116.25 & & \\
\hline \multirow[t]{3}{*}{ Arkadaş } & 1600'e kadar & 71 & 161.04 & & \\
\hline & $1601-4000$ & 119 & 119.74 & 2 & $24.707^{*}$ \\
\hline & $4001-8000$ & 64 & 104.73 & & \\
\hline \multirow[t]{3}{*}{ Okul-Öğretmen } & 1600'e kadar & 71 & 160.20 & & \\
\hline & $1601-4000$ & 119 & 108.41 & 2 & $24.074 *$ \\
\hline & $4001-8000$ & 64 & 126.72 & & \\
\hline \multirow{4}{*}{ okul-öğretmen } & Engel Derecesi & & & & \\
\hline & Hafif & 65 & 114.24 & & \\
\hline & Orta & 151 & 125.97 & 2 & $7.643^{*}$ \\
\hline & A ğır & 38 & 104.95 & & \\
\hline
\end{tabular}

Tablo 2'de sunulan analiz sonuçlarına göre Çocuklar için Yılmazlık Ölçeği'nin aile, kendisi ve okul-öğretmen alt boyutları arasında sadece arkadaş puan sıra ortalamalarında katılımcıların cinsiyetine göre anlamlı bir farkın olduğu görülmüştür. Buna göre OSB'ye sahip kardeşi olan kızların arkadaş kaynaklı yılmazlık düzeyleri erkeklerden daha yüksektir.

ÇYÖ'nün aile, kendisi, arkadaş ve okul-öğretmen alt boyutları arasında sadece aile puan sıra ortalamalarında kardeşin engel türüne göre anlamlı bir fark olduğu görülmüştür. Buna göre kardeşinin engel türü Otizm olan katılımcıların aileden kaynaklı yılmazlık düzeyleri kardeşinin engel türü ÇDB olan katılımcılardan daha yüksektir.

ÇYÖ’nün alt boyutları arasında sadece okul-öğretmen alt boyutu puan sıra ortalamalarında kardeşin bakımına yardımcı birinin varlığına göre anlamlı bir fark olduğu görülmektedir. Buna göre kardeșin bakımına yardımcı birinin olmadığı durumda, katılımcıların okul-öğretmen kaynaklı yılmazlık düzeyi daha yüksektir. 
ÇYÖ'nün alt boyutları arasında sadece arkadaş alt boyutu puan sıra ortalamalarında kardeşin cinsiyetine göre anlamlı bir fark olduğu görülmüştür. Buna göre kardeşinin cinsiyeti kız olan katılımcıların arkadaş kaynaklı yılmazlık düzeyleri daha yüksektir.

ÇYÖ’nün aile, kendisi, arkadaş ve okul-öğretmen alt boyutu puan sıra ortalamalarında, ailenin içinde yer aldığı gelir grubuna göre anlamlı bir farkın olduğu görülmektedir. Gelir grupları arasındaki anlamlı farkların hangi grup ya da gruplardan kaynaklandığını anlamak için ÇYÖ’nün alt boyutlarına göre Mann Whitney-U testi kullanılarak ikili karşılaștırmalar yapılmıştır. Ailesinin geliri 1600 TL'ye kadar katılımcıların, arkadaş ve okul-öğretmen alt boyutu sıra ortalamaları ailesinin geliri 1601-4000 TL arasında olan gruptaki katılımcılardan daha yüksektir. Ailesinin geliri 1600 TL'ye kadar katılımcıların aile, kendisi, arkadaş ve okul-öğretmen alt boyutu sıra ortalamaları ailesinin geliri 4001-8000 TL arasında olan gruptaki katılımcılardan daha yüksektir.

ÇYÖ’nün okul-öğretmen alt boyutu puan sıra ortalamalarında, kardeşin engel derecesine göre anlamlı bir farkın olduğu görülmektedir. Kardeşin engel dereceleri arasındaki anlamlı farkların hangi grup ya da gruplardan kaynaklandığını anlamak için ÇYÖ'nün alt boyutlarına göre Mann Whitney-U testi kullanılarak ikili karşılaştırmalar yapılmıştır. Kardeşin engel derecesi hafif olan gruptaki katılımcıların, okul-öğretmen alt boyutu sıra ortalamaları kardeşin engel derecesi ağır olan gruptaki katılımcılardan daha yüksektir.

\section{Kardeşe Yönelik Tutumu Yordayan Yılmazlık Kaynaklarına İlişkin Bulgular}

Katılımcıların kardeșe yönelik tutum alt boyut puanlarını yordayan değișkenleri belirlemek amacıyla çoklu regresyon analiz sonuçları Tablo 3'de sunulmaktadır.

\section{Tablo 3}

Kardeşe Yönelik Tutum Alt Boyutlarını Yordayan Yılmazlık Kaynakları Alt Ölçek Puanları

\begin{tabular}{|c|c|c|c|c|c|c|}
\hline & $B$ & $T$ & Klsmi R & $R$ & $R^{2}$ & $F$ \\
\hline Yaşama, Duygu ve Düşünce & & & & .394 & .155 & 11.429 \\
\hline Kendisi & .384 & 2.728 & $.170^{*}$ & & & \\
\hline Arkadaș & .860 & 3.688 & $.228 *$ & & & \\
\hline Özellik Düşünce & & & & .398 & .159 & $11.725^{*}$ \\
\hline Arkadaş & .369 & 2.879 & $.180^{*}$ & & & \\
\hline Okul-öğretmen & .440 & 2.932 & $.183^{*}$ & & & \\
\hline Üzüntü ve Endişe & & & & .313 & .098 & $6.760^{*}$ \\
\hline Aile & .253 & 3.202 & $.199^{*}$ & & & \\
\hline Kendisi & -.185 & -2.158 & $-.135^{*}$ & & & \\
\hline Arkadaş & -.504 & -3.556 & $-.220^{*}$ & & & \\
\hline
\end{tabular}

Tablo 3'te sunulan analiz sonuçlarına göre sunulan analiz sonuçlarına göre, yılmazlık alt boyutlarından kendisi $(\beta=.238)$ ve arkadaş ( $\beta=.265$ ) puanlarının yaşama, duygu ve düşünce puanlarını anlamlı şekilde yordadığ $\left[F(4,249)=11.429, P=.000, R^{2}\right.$ adj=.142] ve yaşama, duygu 
ve düşünce puanlarındaki varyansın \% 15.5'ini açıkladığı görülmüştür. Sonuçlara göre ayrıca yılmazlık alt boyutlarından arkadaş $(\beta=.207)$ ve okul öğretmen $(\beta=.233)$ puanlarının kardeşin özelliklerine ilişkin düşünce puanlarını anlamlı șekilde yordadığı $[F(4,249)=11.725, P=.000$, $\mathrm{R}^{2}$ adj=.145] ve özellik düşünce puanlarındaki varyansın \% 15.9'unu açıkladığı görülmüştür. Katılımclların kardeşinin durumuna ilişkin üzüntü ve endişe alt boyut düzeylerinin kendisi (r=.17, $\mathrm{p}=.003)$ ve arkadaş ( $\mathrm{r}=-.23, \mathrm{p}=.000)$ ile anlamlı negatif bir ilişkisinin olduğu bulunmuştur. Son olarak, yılmazlık alt boyutlarından aile $(\beta=.225)$, kendisi $(\beta=-.195)$ ve arkadaş $(\beta=-.264)$ puanlarının üzüntü ve endişe puanlarını anlamlı şekilde yordadığı $[F(4,249)=6.760, P=.000$, $\mathrm{R}^{2}$ adj= ÇYÖ’nün.083] ve üzüntü ve endişe puanlarındaki varyansın \% 9.8'ini açıkladığı görülmüștür.

\section{SONUÇ, TARTIŞMA VE ÖNERİLER}

OSB'ye sahip kardeşi olan bireylerin kardeşlerine yönelik tutumlarına ilişkin araştırmanın bulgularına göre, OSB’ye sahip kardeşi olan sağlıklı bireylerin, kardeşlerine yönelik tutumu cinsiyete göre anlamlı bir fark oluşturmamaktadır. Onat Zoylan'ın (2005) kardeș ilişkilerini belirleme üzerine yapmış olduğu çalışmada da benzer șekilde cinsiyetin anlamlı bir fark yaratmadı̆̆ı bulgulanmıştır.

Bulgularda ayrıca kardeşinin engel türü ÇDB olan katılımcıların kardeşlerinin özelliklerine ilişkin düşünceleri daha olumluyken; kardeşinin engel türü Otizm olan katılımcıların kardeşlerinin durumuna ilişkin üzüntü ve endişesi daha fazladır. Aksoy ve Berçin Yıldırım'ın (2008) farklı engel grubundan kardeşi olan ergenlik dönemindeki çocukların kardeșlerini kabulleri ile ilgili yapmış olduğu çalışmada da engel türlerine göre Otizmli olan kardeşe sahip olan bireylerde olumlu tutumun düşük düzeyde olduğu görülmektedir. Yapılan iki çalışmadaki bulgular bu açıdan benzerlik göstermektedir.

Mevcut araştırmanın bulgularına göre, evde kardeşin bakımına yardımcı birinin olması durumunda sağlıklı bireylerin, kardeşlerinin özelliklerine ilişkin düşünceleri daha olumluyken, bakıma yardımcı birinin olmadığı durumda kardeşin özelliklerine ilişkin düşünceleri daha olumsuzdur. Kahraman ve Karadayı'nın (2015) engelli kardeșe sahip ergenlik dönemindeki çocukların engelli kardeșlerine ilișkin deneyimlerini incelediği araștırmasında da bu sonuçları destekler nitelikte, kardeşiyle iyi vakit geçiren sağlıklı çocukların, engelli kardeşlerinin durumlarıyla ilgili daha olumlu düşüncelere sahip oldukları ve kardeșlerine yönelik olumlu tutum geliştirdikleri bulgulanmıştır.

Bulgularda ayrıca, OSB'ye sahip olan kardeşin cinsiyeti kız ise, sağlıklı olan kardeşin, kardeşinin özelliklerine ilişkin düşünceleri daha olumluyken, kardeşin cinsiyeti erkek ise sağlıklı olan kardeşin, kardeşinin özelliklerine ilişkin düşünceleri daha olumsuzdur. Bu bulgu toplumun 
cinsiyet rollerine ilişkin yüklemiş olduğu etkiler ile ilişkilendirilebilir. Türkiye'de erkek çocukların yetişkin olduktan sonra ekonomik özgürlüklerini kazanmaları, ailesinin geçimini sürdürmek zorunda olmaları gibi yaygın bir inanç ve beklenti görülebilir (Kaypak, 2014). Aykara (2015) zihinsel engelli bireylerin yaşantılarını incelediği araştırmasında engelli kardeşe sahip bireylerin yaşamış oldukları sorunların birçoğunun toplumun cinsiyet rolleriyle ilişkili olduğunu bulgulamıştır. Bu nedenle kızlar ile erkeklerin farklı yaşantılara sahip olduklarını belirtmiștir.

Bulgulara göre, ailelerinin içinde yer aldığı gelir grubu 1600 TL'ye kadar olan OSB'ye sahip kardeşi olan bireylerin kardeşleri ile birlikte yaşama ve kardeşinin özelliklerine ilişkin düşünceleri boyutunda duygu ve düşünceleri daha olumludur. Ailesinin içinde yer aldığı gelir grubu aylık 1601-4000 TL ve 4001-8000 TL arasında olan bireylerin OSB'ye sahip kardeşlerine yönelik üzüntü ve endişeleri, ailesinin içinde yer aldığı gelir grubu aylık 1600 TL'ye kadar olanlara göre daha yüksektir. Buna karşın Ahmetoğlu'nun (2004) kardeş ilişkilerini sağlıklı kardeşin algısına göre incelediği araştırmasında kardeş kabulünde uzak durma çekinme boyutunda ailenin içinde yer aldığı gelir grubunun anlamlı bir fark yaratmadığı görülmüştür. Diğer yandan, aynı çalışmada bu çalışmayı doğrular nitelikte kardeş ile birlikte zaman geçirme ve empati boyutunda ailenin içinde yer aldığı gelir grubu anlamlı bir fark oluşturmuştur.

Araştırmada elde edilen bulgularda, engelli kardeşe sahip bireylerin kardeşlerine yönelik üzüntü ve endişe puanları engel derecesine göre en yüksekten düşüğe doğru sırasıyla ağır, orta ve hafif şeklinde sıralanmaktadır. Engelli kardeşe sahip bireylerin kardeşlerinin özelliklerine ilişkin düşünce puanları engel derecesine göre en yüksekten düşüğe doğru hafif, orta, ağır şeklinde sıralanmaktadır. Engelin derecesinin hafif olması durumunda engelli kardeş, sağlıklı bir bireye daha yakın özellikler gösterdiği için, bakımı, eğitimi, toplumsal hayatın içinde yer alması daha kolay olurken, engel derecesi arttıkça başta bakım olmak üzere pek çok yönden ailesi için gelecek kaygısı yaratmaktadır.

OSB'ye sahip kardeși olan bireylerin yılmazlık düzeylerine ilişkin mevcut araștırmanın bulgularında, OSB'ye sahip kardeși olan bireylerin cinsiyeti kız olanların yılmazlık düzeyleri erkek olanlara göre daha yüksektir. Onat Zoylan'ın (2005) kardeş ilişkileriyle ilgili yapmış olduğu araştırmada kızların erkeklere göre engelli kardeșleriyle daha sıcak ve yakın bir ilişki içinde oldukları bulgulanmıştır. Kızlar genel anlamda toplumda erkeklere göre iletişim becerilerini öğrenmeleri konusunda daha fazla desteklenmektedir. Bu sayede kızların iletişim becerilerinin erkeklere olanla daha iyi durumda olabileceği yorumu yapılabilmektedir (Korkut, 2016). Bu durum kızların arkadaşları ile daha çok duygusal paylaşım içinde olmaları, arkadaşlarından almış oldukları sosyal desteği güçlendirmektedir. Coşkun ve Akkaş'ın (2009) da vurguladığı gibi sosyal destek arttıkça engelli çocuğun varlığının yaratmış olduğu kaygı azalacak ve kişilerin yılmazlığı güçlenecektir. Bu nedenle ergenler engelli bir kardeșe sahip olmanın 
yarattığı zorlayıcı durumlar ile arkadaşlarından aldıkları destek sayesinde daha rahat bașa çıkabilmektedirler. Erkeklerin ise sayıca daha çok arkadaşa sahip olmalarına karşın duygusal paylaşımda bulunma odaklı arkadaşlık kurma becerileri kızlara göre daha zayıf kalabilmektedir.

$\mathrm{Bu}$ bulgulara ek olarak, kardeşinin engel türü Otizm olan bireylerin aile kaynaklı yılmazlık düzeyi, kardeşinin engel türü ÇDB olan bireylere göre daha yüksektir. Otizmin doğuştan ve yavaş yavaş belirtilerini göstermeye başlamasıyla anne baba ve sağlıklı kardeș duruma aşamalı olarak alışıyor. Böylece aile kendini güçlendirecek iç dinamikleri zaman içinde oluşturup engelli çocuğun varlığını daha kolay kabul ediyor olabilir. Buna karşın ÇDB'ye sahip çocuklar doğumdan sonra ilk iki yıl normal gelişim gösterirken, çocuk 3-4 yaşına geldiğinde aile bazen yavaş bazen de ani bir șekilde hastalığın belirtileri ile karşılaşabiliyor. Bu durum ailesinde ÇDB'ye sahip kardeşi olan ergenler için duygusal çöküntüye neden olabilmekte ve aile kaynaklı yılmazlık düzeylerini olumsuz olarak etkileyebilmektedir.

Diğer yandan, kardeşin bakımına yardımcı birinin olmadığı durumda, katılımcıların okul-öğretmen kaynaklı yılmazlık düzeyi daha yüksektir. Engelli bir kardeşin evdeki varlığı sağlıklı olan kardeşin ihtiyaçlarının ikinci planda yer almasına neden olabilmektedir. Engelli kardeş sürekli olarak bakıma ve ilgiye ihtiyaç duyduğu için sağlıklı kardeşin ihtiyaçları özellikle duygusal anlamda yeteri kadar karşılanamamaktadır. Özellikle evde engelli çocuğun bakımına yardımcı birinin olmadığı durumlarda, sağlıklı kardeşin duygusal ihtiyaçları daha çok geri planda kalmaktadır. Bu noktada sağlıklı kardeşin ihtiyaçları okul-öğretmen desteği ile karşılanmaya çalışılmaktadır. Engelli kardeșe sahip olan ergenlerin yaşamış olduğu zorlukların üstesinden gelmeleri için öğretmenleri tarafından daha çok desteklenmektedirler. Bu destek eğitsel olarak akademik yönden takviye, psikolojik olarak duygularını ifade etme ve sosyal olarak herhangi bir faaliyette başarı gösterme olarak şekillenebilmektedir.

Bulgularda ayrıca, kardeşinin cinsiyeti kız olan bireylerin arkadaş kaynaklı yılmazlık düzeyleri kardeșinin cinsiyeti erkek olanlara göre daha yüksektir. Kız çocuklarının herhangi bir engele sahip olmasın ya da olmasın erkek çocuklara göre kişiler arası ilişkilerde daha uyumlu olduğu bilinmektedir (Onat Zoylan, 2005). Bu nedenle engelli kardeşinin cinsiyeti kız olan sağlıklı ergenler kardeşlerini daha rahat arkadaş çevrelerine dahil ediyor olabilirler. Bu durum engelli kardeşin arkadaş çevresi tarafından da kabul edilmesini sağlayacağı için ergenin arkadaş kaynaklı yılmazlık düzeyi daha yüksek olabilir.

Buna ek olarak, ailesinin içinde bulunduğu gelir grubu aylık 1600 TL'ye kadar olan bireylerin aile, kendisi, arkadaş, okul-öğretmen kaynaklı yılmazlık düzeyi ailesinin içinde yer aldığı gelir grubu aylık 1601-4000 TL ve 4001-8000 TL olanlara göre daha yüksektir. Engelli kardeşe yönelik tutumda da belirtildiği gibi ailenin sosyoekonomik düzeyinin artmasıyla birlikte içinde bulunulan sosyal statüyü korumanın yarattığı baskıyla, engelli olmayan kardeș, engelli 
kardeşinin varlığına uyum sağlama konusunda daha fazla güçlük yaşıyor olabilir. Bu durum özünde yılmazlık kavramının doğasıyla doğrudan ilişkili olarak açıklanabilir. Ailesinin içinde yer aldığı gelir grubu aylık 1600 TL'ye olan kadar çocukların, ekonomik düzeyi daha yüksek olan ailelerdeki çocuklara göre zorluklarla daha fazla sınanıyor olma ihtimalleri yüksektir. $\mathrm{Bu}$ nedenle ailesinin içinde yer aldığı gelir grubu aylık 1600 TL'ye kadar olan ergenlerin kardeşlerini olduğu gibi kabul etmelerinde ve içinde bulundukları zorlayıcı durumun üstesinden gelme konusunda sahip oldukları yılmaz kaynaklarının güçlü olma olasılığı daha yüksektir.

Kardeşin engel düzeyi açısından ise, kardeşin engel derecesi hafif olan sağlıklı kardeşlerin, okul-öğretmen kaynaklı yılmazlık düzeyi, kardeşin engel derecesi ağır olan sağlıklı kardeşlerden daha yüksektir. Sağlıklı ergenin kardeșinin bakımıyla ilgilenmesi gereken, ona göz kulak olması için gereken süre daha azdır. Bu nedenle sağlıklı ergen kendi ihtiyaçlarına daha çok zaman ayırabilmektedir. Bununla birlikte derslerine daha fazla zaman ayırabildiği için akademik başarısı yüksek ve okul içindeki faaliyetlerde kendini daha fazla gösterebiliyor olabilir. $\mathrm{Bu}$ durum engel derecesi hafif olan bir kardeșe sahip sağlıklı ergenlerin okul-öğretmen kaynaklı yılmazlık düzeyinin daha yüksek olmasının açıklaması olabilir.

Yılmazlık kaynaklarının kardeșe yönelik tutumu yordayıcılığına ilişkin çoklu regresyon analizi sonucuna göre yılmazlığın aile ve kendisi alt boyutlarının engelli kardeșe yönelik tutumun, kardeşiyle birlikte yaşamaya ilişkin duygu ve düşünce alt boyutunu anlamlı bir şekilde yordadığı bulgulanmıştır. Bu bulgu ergenlik döneminde ergenlerin içsel yılmazlık kaynaklarının güçlendirilmesinin ve arkadaş desteğinin önemini destekler niteliktedir. Ergenlik döneminde ergenin aile desteğinden çok arkadaş desteğini önemsemesi ve bu sayede içsel yılmazlık kaynaklarını güçlendirmesi (özgüven, ait hissetme vs.) OSB'ye sahip kardeşi ile birlikte yaşamaya yönelik olumlu duygu ve düşüncelerini artırmakta ve ergenin karşılaştığı sorunları çözebilecek yeterliliği hissetmesine yardımcı olmaktadır.

Çoklu regresyon analizi sonucuna göre yılmazlığın arkadaş ve okul-öğretmen alt boyutlarının engelli kardeşe yönelik tutumun, kardeşinin özelliklerine ilişkin düşünce alt boyutunu anlamlı bir şekilde yordadığı bulgulanmıştır. Ergenlik dönemi içinde ergenlerin odağı çocukluk dönemine göre daha çok çevreye yönelmektedir. Bu nedenle kendisiyle ve yaşadıkları ile ilgili olarak çevrenin düşüncelerine verilen önem artmaktadır. Bu bulguyu temel alarak, OSB'ye sahip kardeşi olan sağlıklı ergenlerin, arkadaş ve okul-öğretmen desteği ile engelli kardeşlerinin özelliklerine, gelecekte yapabileceklerine ve eğitimlerinde gelişim gösterebileceklerine ilișkin olumlu düşüncelerinin arttığı söylenebilir.

Çoklu regresyon analizi sonucuna göre yllmazlığın aile, kendisi ve arkadaş alt boyutlarının engelli kardeșe yönelik tutumun, kardeşinin durumuna ilişkin üzüntü ve endişe alt boyutunu anlamlı bir şekilde yordadığı bulgulanmıştır. Yılmazlık kaynakları güçlü ve yeterli 
sosyal desteğe sahip olan ergenlerin, zorlayıcı durumlar karşısında baş etme becerilerini daha fazla kullanabildikleri bilinmektedir. OSB'ye sahip kardeşi olan sağlıklı ergenlerin problemler karşısında baş etme becerilerinin gelişmiş olması, ailenin engelli kardeşin durumu ile ilgili yeterli bilgiyi sağlıklı kardeşe vermiş olması ve aile içindeki ilişkilerin sağlıklı işleyiş̧i ve arkadaş desteği ergenin yılmazlık düzeyini yükseltmektedir. Mevcut araştırmanın bulgularına göre, yılmazlık düzeyi yüksek olan ergenlik dönemindeki sağlıklı ergenin, OSB’ye sahip kardeşinin durumuna ilişkin üzüntüsün ve hem şimdi hem de gelecekte kardeşinin eğitimi, bakımı ve sağlığı ile ilgili endişesinin daha düşük düzeyde olabilecektir.

\section{Öneriler}

$\mathrm{Bu}$ araştırmada OSB'ye sahip kardeşi olan ergenlerin yılmazlık kaynaklarının geliştirilerek yılmazlık düzeylerinin yükseltilmesinin engelli kardeşlerine yönelik olumlu tutumu artıracağı bulgulanmıştır. Bu amaç doğrultusunda özel gereksinimli ergenler ile çalışan özel eğitim uzmanların sadece yetersizliğe sahip olan ergene yönelik değil aileye ve kardeşlere yönelik de çalışmalar yapması için rehberlik servislerinden destek almaları önerilebilir.

Özellikle kimlik kazanımı ve gelişim dönemine uyum sağlama sürecinde çatışma yaşayan ergen kardeşleri sürece dahil edip engelli kardeşin varlığının öğrenildiği andan itibaren bilgilendirici ve destekleyici çalışmaların başlatılması ve yaygınlaştırılması önerilebilir.

Ayrıca engelli kardeșe sahip ergenlik dönemindeki ergenlerin de sürece dahil edilmesi ve psikolojik olarak desteklenmesi adına, okul psikolojik danışmalarına hizmet içi eğitim verilmesi ve bu sayede okul içinde de desteğin sürdürülmesi önerilebilir.

OSB ve diğer engel türlerinden kardeșe sahip olan ergenlik dönemindeki ergenlere yönelik bilgi verici eğitim gruplarının ve psikolojik destek gruplarının yaygınlaştırılması için bu alanda çalışan araştırmacıların program içeriği geliştirmeleri ve bu programların etkililiğinin sınanması önerilebilir.

Bu araştırmada ergenlik dönemindeki bireyler ile çalışılmıștır. Farklı gelişim döneminde yer alan çocukların kardeşlerine yönelik tutumlarında değişiklik olması nedeniyle farklı yaş grubunda yer alan kardeşler üzerinde de karşılaștırma yapabilmek için aynı veya benzer çalışmaların yapılması önerilebilir.

$\mathrm{Bu}$ araștırmada OSB'ye sahip çocukların ergenlik dönemindeki engelli olmayan kardeşleri ile çalışılmıştır. Farklı engel gruplarında yer alan engelli kardeşler konu alınarak aynı veya benzer çalışmaların yapılması önerilebilir.

Bu çalışmada nicel bir araştırma yöntemi kullanılmıștır. Engelli kardeşe sahip ergenlerle ilgili daha derinlemesine bilgilere ulaşmak için nitel çalışmalar yapılması önerilebilir. 
Son olarak günümüzde bilgisayarın hayatımızın neredeyse merkezinde yer alması ve ergenlik dönemindeki çocukların bilgisayarla gün içinde daha çok vakit geçirmesi nedeniyle OSB ve diğer engel gruplarından kardeşi olan ergenlere yönelik duygularını paylaşabilecekleri çevrimiçi destek gruplarının geliştirilmesi ve etkililiğinin sınanması önerilebilir.

\section{KAYNAKÇA}

Ahmetoğlu, E. \& Aral, N. (2004). Zihinsel engelli çocukların kardeş ilişkilerinin anne ve kardeş algılarına göre değerlendirilmesi [Yayımlanmamış Doktora Tezi]. Ankara Üniversitesi.

Aksoy, A. B. \& Yıldırım, G. B. (2008). Farklı engel grubundan engelli kardeşe sahip çocukların kardeş ilişkileri ile kardeşlerini kabullenmeleri arasındaki ilişkinin incelenmesi. Kuram ve Uygulamada Eğitim Bilimleri, 8(3), 751-779.

Aykara, A. (2015). Zihinsel engelli kardeșe sahip bireylerin yaşantılarının değerlendirilmesi [Yayımlanmamış Doktora Tezi]. Hacettepe Üniversitesi.

Baltacı, H. Ş. \& Karataş, Z. (2015). Ortaokul öğrencilerinin yılmazlık düzeylerinin yordayıcısı olarak algllanan sosyal destek, depresyon ve yasam doyumu: Burdur örneği. EurasianJournal of Educational Research, 15(60), 111-130. https://doi.org/10.14689/ejer.2015.60.7

Bear, G. G., Manning, M.A. \& Izard, C. E. (2003). Responsible behavior: The importance of social cognition and emotion. School Psychology Quarterly, 18(2), 140-157. https://psycnet.apa.org/doi/10.1521/scpq.18.2.140.21857

Burke, P. (2004). Brothers and sisters of disabled children. Oxford: Jessica Kingsley Publishers.

Büyüköztürk, Ş., Kılıç Çakmak, E., Akgün, Ö.E., Karadeniz, Ş. \& Demirel, F. (2018). Eğitimde bilimsel araștırma yöntemleri (25. Baskı). Pegem Akademi.

Coşkun, Y. \& Akkaş, G. (2009). Engelli çocuğu olan annelerin sürekli kaygı düzeyleri ile sosyal destek algıları arasındaki ilişki. Ahi Evran Üniversitesi, Kırşehir Eğitim Fakültesi Dergisi, 10(1), 213-227.

Clonan, S. M., Chafouleas, S. M., Mc Dougal, J. L. \& Riley-Tillman, T. C. (2004). Positive psychology goes to school: Are we there yet? Psychology in the Schools, 41(1), 101-110. https://doi.org/10.1002/pits.10142

Çelik, E. (2013). Lise son sınıf öğrencilerinin yılmazlık özelliklerinin duygusal dişavurum açısından incelenmesi. Atatürk Üniversitesi, Sosyal Bilimler Enstitüsü Dergisi, 17(2).

Dolanay, D. (2016). Ailelerin özel gereksinimli çocuklarını kabul etmeleri ile kardeșlerin özel gereksinimli çocukları kabulü arasındaki ilişki [Yayımlanmamış yüksek lisans tezi]. Yakın Doğu Üniversitesi.

İçöz, A. (2001). Zihinsel engelli bir çocuğa sahip aile bireylerinin kaygı düzeylerinin incelenmesi. Cocuk Gelișimi ve Eğitimi Dergisi, 1 (6), 80-90.

Kahraman, Ö. \& Karadayı, N. (2015). Engelli Kardeşe Sahip Olan Çocukların Engelli Kardeşleriyle Deneyimlerine İlişkin Görüșleri. Hacettepe Üniversitesi, Sağlık Bilimleri Fakültesi Dergisi, 2(1), 390-408.

Kaypak, Ş. (2014). Toplumsal cinsiyet bakıș açısından kente bakmak. Niğde Üniversitesi İktisadi ve İdari Bilimler Fakültesi Dergisi, 7(1), 344.

Korkmaz, A. (2008). Özel eğitim alan zihinsel engelli çocukların kardeşleri ile iliş̧ilerinin değerlendirilmesi. Gülhane Tıp Akademisi Sağlık Bilimleri Enstitüsü.

Korkut, F. (2016). İletişim becerilerini değerlendirme ölçeğinin geliştirilmesi: güvenirlik ve geçerlik çalışmaları. Türk Psikolojik Danışma ve Rehberlik Dergisi, 2(7), 18-23. 
Küçüker, S. (1997). Bilgi verici psikolojik danışmanlık programının zihinsel özürlü çocukların kardeșlerinin özürle ilgili bilgi düzeylerine ve özürlü kardeşlerine yönelik tutumlarına etkisi [Yayınlanmamış doktora tezi]. Ankara Üniversitesi.

Masten, A. S. \& Reed, M. G. J. (2002). Resilience in development. C. R. Snyde ve Shane J. Lopez (Ed.), Handbook of positivepsychology. (117-125). New York: Oxford University Press.

Newman, T. (2004). What works in building resilience? Barkingside: Barnardo's.

Olsson, C. A., Bond, L., Burns, J. M., Vella-Brodrick, D. A., ve Sawyer, S. M. (2003). Adolescent resilience: A concept analysis. Journal of adolescence, 26(1), 1-11. https://doi.org/10.1016/s0140-1971(02)00118-5

Onat Zoylan, E. (2005). Engelli kardeșe sahip olan ve olmayan bireylerin kardeș ilişsilerinin belirlenmesi [Yayımlanmamış yüksek lisans tezi]. Abant İzzet Baysal Üniversitesi. 


\section{EXTENDED ABSTRACT}

\section{Introduction.}

The first aim of this study is to examine whether there are significant differences in resilience sources and the attitudes of individuals who have siblings with Autism Spectrum Disorders (ASD) in terms of some demographic variables. The second aim of the study was to investigate whether resilience sources of individuals with siblings with ASD predict their attitudes towards disabled siblings.

\section{Method.}

The study group is composed 254 adolescents who have siblings with ASD, living in Denizli and İzmir. Due to the difficulty in reaching participants, the study group was selected from the siblings of the students attending various secondary and high schools and special education centers in Denizli and İzmir. The data is collected between 2016 and 2018 years. A total of 254 students were reached in the study. The age range of participants ranged from 11 to 18, of which 123 were girls and 131 were boys. In this study, data collection instruments were Attitude Scale for Disabled Sibling, Resilience Scale for Children and Personal Information Form prepared by the researchers.

\section{Results.}

According to the results of Mann Whitney-U test, there was a significant difference in the sub-dimension of resilience sources according to gender variable. It was found that there was a significant difference in resilience sources in the family sub-dimension and attitude towards the sibling, thought about the characteristics of the sibling, and sadness and anxiety about the sibling's status. It was found that there was a significant difference in school-teacher subdimension and thought about the characteristics of the sibling sub-dimension of attitude towards the sibling according to presence of helper for the care of the child. It was found that there was a significant difference in resilience sources according to the gender of the sibling variable in the sub-dimension of friends and in the thought sub-dimension of the attitude towards the sibling. According to the results of the Kruskal Wallis test, there was a significant difference in all sub-dimensions of resilience sources and attitude towards siblings according to family's income group variable. According to the degree of disability, there was a significant difference in resilience sources in the school-teacher sub-dimension and the attitude towards the sibling about the characteristics of the sibling and sadness and anxiety about the sibling's status.

As a result of multiple regression analysis, it was found that the resilience sources significantly predicted the emotion and thoughts about living with his sibling. Among the 
resilience sources, it was found that the sub-dimensions of friends and school-teachers significantly predicted the thoughts about sibling's characteristics. Among the resilience sources, it was found that the sub-dimensions of family, oneself and friends significantly predicted sadness and anxiety about the sibling's status.

\section{Discussion \& Conclusion.}

The siblings of the participants whose sibling type is MDD had more positive thoughts of children; Participants with a sibling's disability type Autism had more worrying about painting and painting siblings. According to the sibling types of Aksoy and Berçin Yıldırım (2008), who are the user in adolescence, other than different disability groups, siblings with autism have a low level of positive attitude.

According to the findings obtained in the study, the sadness and anxiety scores of individuals with a disabled sibling for their siblings are ranked from the highest to the lowest according to the degree of disability as heavy, moderate and mild, respectively.

According to the findings of the current research on the resilience levels of individuals with ASD siblings, the resilience levels of individuals with siblings with ASD are higher than those of boys. In the research conducted by Onat Zoylan (2005) on sibling relationships, it was found that girls have a warmer and closer relationship with their disabled siblings than boys. 